\title{
The Mythical Context of Magic as an Influential Power on the Plot Development in Thomas Malory's Le Morte Darthur
}

Baker Mohammad Jamil Bani-Khair*

Hashemite University, Zarqa, Jordan

Corresponding Author: Baker Mohammad Jamil Bani-Khair, E-mail: bakribakr@yahoo.com

\section{ARTICLE INFO}

Article history

Received: September 14, 2017

Accepted: November 18, 2017

Published: December 30, 2017

Volume: 8 Issue: 6

Advance access: December 2017

Conflicts of interest: None

Funding: None

Key words:

Devilish,

Magic,

Le Morte Darthur,

Supernatural,

Thomas Malory,

Fantasy

\begin{abstract}
This paper studies the mythical context of magic in Thomas Malory's Le Morte Darthur through a critical lens that focuses the light on plot development and the use of suspense throughout the novel. The study places the emphasis on a major character named "Merlyn" who seems to have a great influence on the plot and actions of the novel through his devilish and mythical prophecies about characters and places. The context of magic is quite essential in understanding the nature and structure of fantasies that all yield a huge amount of suspense, in addition to its historical, social, and traditional significance.
\end{abstract}

\section{INTRODUCTION}

This paper discusses the representations of magic represented by the major character in Thomas Malory's Le Morte Darthur (1485) and its influence on the plot development. The theme of the supernatural and mythical context of magic is a common and abundant issue throughout the novel. The richness and dominance of this theme throughout the romance creates a sense of suspense and makes the plot moves forward in accordance with this issue. This mythical context is primarily represented by magic as a fictional power of influence that signifies a legend and helps to develop the plot into real actions and visible incidents that promote suspense, and capture attention. Magic in Malory's romance controls the plot and maintains the flow of actions whether created by persons such as Merlin as a sorcerer, or the scenes of knighthood and the chivalric heroism such as fights and conflicts among the knights. I am arguing in this paper that magic is seen as a very powerful and influential factor that not only gives suspense, but also controls chivalry and knighthood, and, therefore complicates and sophisticates the course of actions throughout the novel. It appears as a devilish power that interferes with destinies of knights and, thus changes political plans and actions. Magic seems to play a significant factor in guiding prophecies, controlling potential events, and foreshadowing death, downfall and doom. Interestingly enough, magic and prophecy also seem to overlap with each other from the very beginning of the story. They appear as one issue in terms of their significance and influence in moving the plot forward. From the very beginning of the Romance, Merlin is seen as a master of magic who has got all that attention from all knights and people around him. Merlin is depicted as a designer of the plot who can change and replace whatever he wants. He appears as the one, who can anticipate the very far future, foretells future of the kingdom and the people and also interferes with the political and social events, and even manipulates things as he wishes because of the invincible power he seizes. As Dean explains in his book entitled, The Study of Merlin in English Literature from the Middle Ages to the Present that Merlin's prophecies are political but foreshadow rebellion and doom. Dean says, "Political Prophecies tend to be associated with rebellion and sedition and Merlin's prophecies are no exception" (63). In other words, the romance seems as a story of magic that tells the story of a magician and his prophecies rather than being a story of a king and his kingdom.

\section{DISCUSSION AND ANALYSIS: THE DEVILISH PACT AND ITS EFFECT ON THE PLOT}

Readers are introduced to the supernatural and devilish magical atmosphere through Merlin's character from the very beginning of the romance showing the highly supernatural 
status of Merlin, who interferes with the destiny of the kingdom, especially paving the way for Arthur to be a king and help him seize his reign. It is very noticeable here that Merlin's character is directly linked with the royal decision and the whole Arthurian kingdom. The dominance of this theme actually can trigger both; the sense of suspense and the move of the plot which can promote our imagination simply because it appears as a fantasy rather than a realistic and artistic literary creation. The more we delve in the romance and unravel the plot, the more we get the sense of the impact of magic on every single move in the plot through developing, changing and sophisticating the plot towards the very end of the whole story. From the very outset, we see how Merlin could see and even change the future of the kingdom. Merlin's magic is depicted as an extraordinary power sought after by rulers in order to help them maintain superiority and sovereignty over their own kingdoms. Moreover, that magical power Merlin has is also embodied as more of ultimate power that is seen as a source of intriguing evil which actually creates terror, but also suspense and excitement. For example, the deal he has with the king reminds me with Dr. Faustus's pact with the devil "Mephistopheles" in Christopher Marlowe's Dr. Faustus, simply because that deal is based upon a transitory pure desire that satisfies an insatiable search for authority. It's very similar to that pact we see Dr. Faustus made with the devil just for the sake of power and control. As we see in this quotation that shows the deal between Merlin and the king which was done on certain conditions that seems evil though it creates suspense and makes us anticipate what is going to happen as the plot moves forward:

So ulfius deprted; and by adventure he mette Merlyn,in a beggars aray.And ther Merlyn asked ulfius whom he sought; and he said he had lytl ado to telle hym. "well,"said Merlyn, "I knowe whome thou sekest, for thou sekest Merlyn; therefore seke no ferther,for I am he.And yf kynge Uther wille wel rewarde me and be sworne unto me to fulfille my desire, that shall be his honour and profite more than myn, for shalle cause hym to have all his desire. (4).

In fact, that kind of a deal between the king and Merlyn signifies the importance of Merlin's character as a devilish person who could influence things and actions. This affects what happens in the kingdom, but also creates a sinister atmosphere that activates motivation and excitement. In this sense, I see Merlin as 'Mephistophilis' the devil in Christopher Marlowe's Dr. Faustus who promises to grant Dr. Faustus with whatever he wishes to do. Dean argues in his book, The Study of Merlin in English Literature from the Middle Ages to the Present that Merlin's magic can just be seen as evil and warning for the whole kingdom. He says, "Merlin is more than just an inspired voice fatefully but hopelessly warning mankind of the doom that awaits it" (27).

Merlin's appearance in this romance amplifies the imaginative and legendary existence of magic and its impact on the plot, however; this legendary association of magic with his legendary appearance in this romance does make us see the imaginative and supernatural part of this story and increases our sense of suspense which makes us follow up and anticipate the forthcoming events that the agreement entails. The supernatural and legendary association of Merlin with magic and power also makes us see the dimensions of the prophecy he tells. In other words, Merlin's character is not only associated with Magic, but it is also linked with prophecy, foretelling, and even with sharp wisdom and insight. Pochoda tells us in Arthurian Propaganda about Merlin's prophecy saying, "the French romance is content to have Merlin prophecy that Arthur will be king" (78)

As we see in the following quotation, Merlyn seems as a person who has the supernatural knowledge and experience and even the expertise of personalities. In this example, Merlin appears to us as an excellent judge of characters with the most invincible power, "Whan kyng Uther sawe hym, he said he was welcome. " syr, " said Merlyn, "I knowe al your hert, every dele. So ye wil be aworn unto me, as ye be a true kynge enoynted, to fulfille my desire, ye shal have your desire." Thenne the kyng was sworne upon the four Evangelistes" (4) Merlin is seen here as a person who has got the authority and control over the whole kingdom since he can use his supernatural and magical power to change, control and make others' royal dreams come true.

We best understand the authority and the centrality of Merlin's character in the story once we see how influential he is on the construction and the political structure of the kingdom. This centrality is made because Merlin has the power which others don't have at all. It is true that Merlin's character is legendary and fictional because it is depicted in the story as the most incredible imaginative and devilish character, and also by associating this legendary character with ultimate power and magic that is almost unbelievable. But still that character stimulates the sense of suspense and excitement and arouses the sense of fear since we become interested in following every single aspect, and every single action done by Merlin.

\section{SUSPENSE AND MAGIC}

Suspense is synchronized with the passion we get towards King Arthur and also for the Kingdom. Since Merlin was the advocate and the trusted person to King Arthur, we actually become more curious to know how Merlin can change things, and to what extent, he can maintain stability and power for the Arthurian kingdom. Merlin seems almost as the most powerful character besides being the most sincere counselor for King Arthur as we see in this quotation from the story when Arthur keeps asking him about things, people, future, "Now, Merlin," seyde Arthure," whether thys Torrw shallo be a goode man?, and Merlin asnswerd him "yee, hardely, sir, he ought to be a good man,for he ys com of good kynrede as ony on lyve-and of kynges bloode."

In fact, what also attracts the attention of readers about the supernatural and the mythical things in association with magic is the use of fictional creatures like the dragons which have never existed in the middle ages or even the ages before at all. It seems to me that the references to the fictional creatures just gives us the sense that all the story is just fictional and all fabricated imagination which has no grounds 
on reality at all. It seems that the whole romance is merely a representation of a fantasy though it might not be considered a reliable source to provide details on heroism, knighthood, and chivalric code in the middle ages. Simply, it all appears as a myth which is more governed by a fictional sorcerer whom we do not know anything about his background, but we always hear about as a legendary character known for his magic and power.

\section{THEMES AND CONTEXTS}

Magic in Le Morte Darthur seems to represent important dimensions in the romance. First of all, the use of magic with its legendary association with dragons, sorcery, evil, imagination, delusion and enchantment provides more identification and creates more familiarity with the text as we move ahead. However, we should also bear in mind the centrality and the significance of magic on the plot itself and how it goes on as magic sophisticates the plot or probably makes us think of its complexity from the very beginning. For example, Merlin from the very beginning of the romance distorts realities by his magic, and changes the course of the plot from the very early outset when he uses his devilish magic to let Uther sleep with the duke's wife in the likeness of her lord begetting Arthur the king of the kingdom later. What makes this so important because I see that Merlin in this way with his magic has drawn the future of the plot from the outset. And even the sins of lust and adultery from the beginning can probably be seen as the original sin for all the adultery and courtly love we see later on as the most common motif and drive for the whole plot or the whole romance. In other words, the sin that Merlin caused to happen is a parallel to the whole theme of adultery and sin we see throughout the story which, from my point of view, might be an allegory for the original sin.

We can see the abominable effects of the sin of adultery that was done by the mean of Merlin's use of his evil magical power to pervert and falsify realities and distort truths. From my point of view, I guess that Merlin's magical power is completely evil in that it spreads evil and sin from the start. Probably, Merlin's magical power not only caused adultery to happen but also paved the way for killing, fight, and courtly love. Despite the power he uses which made Arthur a king, but it also brings the downfall of the ethical and moral façade of knighthood simply because it caused blood shedding from the very beginning of the romance. While I believe that magic creates suspense in the romance because it opens our minds to imagination and fantasy but I also believe that it controls the plot due to its dual role in the whole story. From my point of view, I see that the mythical reference to magic in this romance needs a further investigation to study how it was looked at in the Middle Ages and to what extent people believed in it. Sweeney says in his book Magic in Medieval Romance that magic is something that should never be ignored in all medieval romances because it plays more of a social, theological, a moral role in all of the medieval romances. He says, "The strength of the influence of magic on medieval society requires that the modern reader should approach the romances with a keen eye to its function in them. This brief overview only sets the stage for what is a long and complicated history of magic in the medieval world. To fail to acknowledge its influence is to diminish and oversimplify a phenomenon which medieval authors saw as a means of interrogating their own community's sense of self and purpose. If one ignores the function of magic in the romances, then a fruitful source of controversy and exploration of social, theological, and moral issues is lost" (53).

I would rather agree with Sweeney when he explains that magic serves a function in the romance and that function should not be oversimplified simply because it interferes with every single aspect in the course of events including love. As we see throughout the whole romance magic seems much more like a driving force that maintains both vitality and excitement. This diverse and ramified function that magic severs in Le Morte Darthur gives us a wide range of images and patterns about the imaginative significance of the use of magic in the fourteenth century. Sweeney says," The important role of magic in medieval society is mirrored by its crucial place in the literature of the period. In understanding and appreciating how romance writers carefully manipulated it, one is exposed not simply to a story of adventure but to a political and social analysis of some of the most important facets of medieval culture."(169).

Regarding what Sweeney explains, magic is seen as a manipulating force that can also interfere even with the political and social structure of a whole country of the legendary Arthurian Kingdom. Apparently, magic is used to restructure and change a political order which is considered the most significant issue here in the whole romance. Also, it is used to change sub-plots in the romance by tricking knights, changing realities and causing the plot to change. As we see to what happened with Tristan when he drank the love potion which is apparently a form of magic. While magic is used to cause troubles and evil deeds and changes the course of events in the romance, still it is also used in the same way to restore the normal life for the knights whom we frequently see behind the scenario of knighthood and chivalry. We rather see a lot of incidents in which magic is used to heal the wounded knights, or to remove a spill or even to give more empowerment as we see with Tristan. Apparently, the frequent use of magic that severs multifarious perspectives can evidently make us think of the main plot and how it was planned or even prophesized by Merlin. However, I'm not arguing here about the actuality or the real grounds of magic in the middle ages but certainly I'm stressing here the imaginative role the magic has in this medieval romance though we see some critics like Sweeney who even argues that magic had a real place in medieval society which from his point of view was not only located in the imagination" (45).

\section{CONCLUSION}

In fact, the fictional and supernatural themes and contexts do not stop at a point where magic is seen as an imaginative force that can change actual realities and plots, but they also extend to include certain mythological implications that we see throughout the romance. To me, the sword or "Excalibur" is one of these things that also fall under the theme of 
magic. Arthur wouldn't be a king without that magical power which helped him pull the sword out of the stone. Arthur wouldn't pull out that sword without magic and the prophecy Merlin sees in him as a king. Logically speaking, the scene of pulling out the sword from the stone causes a lot of bewilderment and astonishment for me as a reader. Magic is the most central issue in the whole romance as it correlates with destiny and fate because it imposes a fictional and supernatural sense that is almost bloody, dark and gloomy. Sweeney argues in Magic in Medieval Romance that magic is a power that is almost needed by all the knights starting from King Arthur and ending with Lancelot. He argues that magic for these knights is seen as guidance, council, wisdom, remedy, and even salvation. He mentions Lancelot as an example who was looking for his magical ring to save him from the trap. Sweeney says, "Compare that adventure to Lancelot's; when a closed portcullis in a bailey under siege traps the lover, he looks for guidance to a magical ring given to him by his fairy family. It's interesting that he requires magic to see reality. His idealized love for Guinevere may well thrive in that same fairy world, which would put in perspective why it is that Lancelot's morality of love is failing to function very effectively in Arthur's world" (84).

Part of that connection to magic, I would also stress the point here that King Arthur himself was always in a dire need for Merlin's magical power without which Arthur would never know how to rule and control his kingdom. Moreover, Merlin's magical power and insight was also needed by King Arthur for his own personal and social life. Tristan is also another example from the story of how one can be just totally mad of love due to love enchantment caused by drinking a magical love potion. Actually, this lovesickness was a real cause for more journeys, agonies, sadness, and most importantly blood shedding. Tristan's enchantment is seen as a myth here due to the fact that his love was caused by magic which rather makes him as a legend. Weston refers to Tristam as a legend in his book King Arthur and his Knights when he says, "As a consistent and connected story, the Tritsan legend probably took shape earlier than the Arthurian romances proper. Though it has undergone considerable development, the central motif, the love of Tristan for Iseud, his uncle's wife, has known no change. There is no moment in the Tristan, as in the Lancelot, legend to which you can point as being anterior to the introduction of the love element" (26). From my point of view, magic makes Tristam appears as a legend and we get the sense of suspense when we hear of love potions simply because they usually strike fear, but certainly I wouldn't exclude the stereotypical and the mythical archetypes that might have been common in the middle ages.

Another supportive example that might advocate my argument here is that magic was always behind the scenario of chivalry and knighthood creating what I would call "the invincible or the supreme power". How many times throughout the whole story we see Tristan being shot by poisonous arrows and spears and never died, but always healed by magic. This thing also applies to King Arthur, Gawain, and most of the Knights of the Round Table. I would really support the point here that magic might be seen as part of chivalric code simply because all the strong knights we see here seem to be affected by it or probably having it.

Finally, I would really emphasize the importance of the references to the mythical context represented by magic, especially for the modern reader who might ignore these references or even exclude its grounds and contexts in the middle ages, but certainly these references are of high value that can enhance a better reading of a literary, contextual, and mythical text such as Le Morte Darthur. Magic in Le Morte Darthur is a driving force even though it is mostly associated with devilish contexts that represent evil and doom, but yet it creates a big deal of suspense and amusement.

\section{REFERENCES}

Sweeney, Michelle. Magic in Medieval Romance from Chretien de Troyes to Geoffrey Chaucer. Dublin: Four courts press, 2000.

Shepherded, Stephen. Sir Thomas Malory Le Morte Darthur.New York:2004

Weston, Jessie. King Arthur and his Knights.New York: AMS Press INC, 1972.

Dean, Christopher. A Study of Merlin in English Literature from the Middle Ages to the Present Day: The Devil's Son. Lewiston, New York: The Edwin Mellen Press.1930. 